\title{
STABILITAS, TOTAL POLIFENOL, DAN AKTIVITAS ANTIOKSIDAN MIKROEMULSI EKSTRAK CASCARA (TEH KULIT KOPI) MENGGUNAKAN MINYAK KELAPA DAN MINYAK KELAPA SAWIT
}

The Stability, Polyphenols Total and Antioxidant Activity of Cascara Extract Microemulsion Using Coconut Oil and Palm Oil

\author{
Sih Yuwanti ${ }^{1)}$, Triana Lindriati $^{1) *}$, Renny Dwi Anggraeni ${ }^{1)}$ \\ ${ }^{1)}$ Jurusan Teknologi Hasil Pertanian, Fakultas Teknologi Pertanian, Universitas Jember \\ Jalan Kalimantan 37, Kampus Tegal Boto Jember 68121 \\ *E-mail: lindriatitriana@unej.ac.id
}

\begin{abstract}
ABSTRACK
Coffe cherry tea or cascara contained the compound of polyphenol class such as tannin, flavanol, flavan-3-ol, hydrazine acid, antosianin. The compound is very sensitive to oxygen and light because it is easily oxidized. Microemulsions can control both the active ingredient and can protect the active component from undesirable oxidation. Mikoemulsions is composed of water, oil, and food surfactant. Vegetable oil sources that can be applied in microemulsion are coconut oil and palm oil. The addition of cascara extract to microemulsion is expected to provide functional value of microemultion. However, the addition of cascara extract in microemulsion formulation affected the stability of microemulsion system. The objective of the research was to determine the effect of oil and cascara to stability of microemulsion, content of polyphenol and the antioxidant activity of microemulsion. The result showed that the kinds of oil variation given significantly effect for the microemulsion stability. The palm oil resulted the higher absorbance than coconut oil. The concentration of cascara extract had significantly effect for the microemulsion stability. The variation of cascara extract increased the absorbance value and significantly effect to the polyphenol total and antioxidant activity.
\end{abstract}

Keywords: cascara, coconut oil, lecithin, microemultion, palm oil, tween 80

\section{PENDAHULUAN}

Cascara merupakan bahan yang mengandung senyawa mengandung senyawa polifenol berupa antosianin, tanin, flavonol, flavan-3-ol, asam hidraksinat dan kafrin (Esquivel dan Jimenez, 2012). Senyawa tersebut mampu berperan sebagai antioksidan. Penelitian mengenai kemampuan aktivitas antioksidan cascara telah banyak dilakukan (Mahesa, 2012; Ariadi, 2015 dan Marcelinda, 2016). Salah satu sifat dari senyawa antosianin yaitu mudah teroksidasi. Houghton (1998) menyatakan bahwa antosianin sangat sensitif terhadap oksigen dan cahaya karena mudah teroksidasi. Oleh karena itu diperlukan suatu sistem yang mampu untuk mencegah atau mengurangi oksidasi senyawa aktif tersebut. Mikroemulsi mengontrol dengan baik bahan aktif dan dapat melindungi komponen tersebut dari oksidasi (Garti et al., 2001). Penelitian Cho et al. (2008) bahwa minyak DHA yang dimasukkan ke dalam mikroemulsi $\mathrm{O} / \mathrm{W}$ menunjukkan stabilitas oksidatif yang tinggi, yang menunjukkan bahwa sistem mikroemulsi ini efektif untuk melindungi bahan-bahan yang sensitif terhadap oksidasi. Penelitian mengenai mikroemulsi sebagai sistem pembawa zat aktif dan memiliki stabilitas oksidatif lebih tinggi yaitu likopen (Spernath et al., 2002), lutein (Amar et al., 2002), phitosterol (Spernath et al., 2003), tokoferol (Yuwanti et al., 2012) dan fucoxanthin (Suhendra et al., 2014).

Mikroemulsi adalah suatu sistem dispersi minyak dengan air yang dikembangkan dari sediaan emulsi dan distabilkan oleh lapisan antarmuka dari 
molekul surfaktan. Mikroemulsi memiliki banyak kelebihan dibandingkan dengan emulsi biasa yaitu bersifat lebih stabil jernih, transparan, dan mempunyai tingkat solubilitas yang tinggi karena tegangan antarmukanya rendah (Flanagan dan Singh, 2006).

Mikoemulsi tersusun dari air, minyak, dan surfaktan (Cho et al., 2008). Sumber minyak nabati yang melimpah di Indonesia dan dapat diaplikasikan dalam mikroemulsi yaitu minyak kelapa dan minyak kelapa sawit. Minyak kelapa tersusun oleh asam lemak jenuh lebih dari 90\% dan asam lemak rantai sedang serta rantai pendek (Silalahi dan Nurbaya, 2011). Asam lemak utama penyusun minyak kelapa sawit adalah asam palmitat merupakan asam lemak rantai panjang dari C12 sampai C20 (Basiron, 2005). Asam lemak jenuh dalam minyak kelapa sawit hanya sekitar 50\%. Perbedaan komposisi asam lemak dalam minyak akan berpengaruh terhadap stabilitas mikroemulsi yang dihasilkan.

Penambahan ekstrak cascara pada mikroemulsi diharapkan dapat memberikan nilai fungsional. Namun penambahan ekstrak cascara dikhawatirkan dapat mempengaruhi kestabilan mikroemulsi. Salager et al. (2005), menyatakan bahwa formulasi dalam pembuatan mikroemulsi sangat penting, karena sedikit pergeseran dari formulasi yang tepat dapat menyebabkan perubahan drastis pada sifat mikroemulsi. Oleh karena itu, pada penelitian ini perlu dikaji untuk mengetahui pengaruh penggunaan jenis minyak dan penambahan ektrak cascara terhadap stabilitas mikroemulsi, kadar total polifenol, dan aktivitas antioksidan mikroemulsi.

\section{METODE PENELITIAN}

\section{Alat dan Bahan}

Alat-alat yang digunakan dalam penelitian ini adalah neraca analitik (Denver Instrument XP-1500), hot plate
IKA C-MAG HS 7, magnetic stirrer SM 24 Stuart Scientific, beaker glass $500 \mathrm{ml}$ (pyrex), thermometer, kain saring, spatula, beaker glass $100 \mathrm{ml}$ (Duran), pipet tetes, gelas ukur $100 \mathrm{ml}$ (pyrex), dan stopwatch Alat untuk analisis meliputi oven listrik, sentrifuse (Yenaco model YC-1180), tabung reaksi (pyrex), beaker glass $250 \mathrm{ml}$ (pyrex), spektrofotometer UV-Vis (Shimadzu 1650 PC), cuvet, pipet mikro, pipet ukur, botol timbang, dan vortex (Maxi Max 1 type 16700).

Bahan dalam pembuatan selai koro pedang antara lain cascara (kawasan Ijen Bondowoso-Jawa Timur), minyak kelapa sawit (Bimoli), minyak kelapa (Ikan Dorang), Tween 80 teknis food grade, lesitin teknis food grade dan aquades. Bahan untuk analisis antara lain cascara (kawasan Ijen Bondowoso-Jawa Timur), minyak kelapa sawit (Bimoli), minyak kelapa (Ikan Dorang), Tween 80 teknis food grade, lesitin teknis food grade dan aquades.

\section{Tahapan Penelitian}

\section{Pembuatan Ekstrak Cascara}

$500 \mathrm{~mL}$ aquades dipanaskan menggunakan hot plate hingga suhu $100^{\circ} \mathrm{C}$. Selanjutnya ditambahkan 2 gram cascara dan diladuk selama 10 menit. Selesai ekstraksi dilakukan penyaringan menggunakan kain saring sehingga didapatkan larutan ekstrak cascara. Larutan ekstrak cascara dilakukan pendinginan hingga mencapai suhu ruang dan siap digunakan dalam pembuatan mikroemulsi.

\section{Pembuatan Mikroemulsi}

Pembuatan mikroemulsi dilakukan dengan mencampurkan 9 gram campuran minyak kelapa sawit/minyak kelapa dan surfaktan pada nilai HLB tertentu dengan perbandingan 15:85 dan dipanaskan pada suhu $50 \pm 5^{\circ} \mathrm{C}$ sambil diaduk menggunakan hot plate magnetic stirrer selama 5 menit. Tujuan dari pengadukan ini untuk menghomogenkan campuran minyak 
dengan surfaktan, kemudian ditambahkan ekstrak cascara sedikit demi sedikit dengan variasi rasio ekstrak cascara:akuades $(0: 100 ; 50: 50 ; 100: 0)$ dengan variasi rasio minyak-surfaktan dan ekstrak adalah 1:8 serta tetap dipanaskan dan diaduk hingga total waktu pemanasan 17 menit. Kecepatan pengadukan disesuaikan dengan volumen campuran. Hasil mikroemulsi yang diperoleh disimpan pada suhu kamar selama 24 jam. Terbentuknya mikroemulsi ditandai oleh kenampakan yang jernih dan transparan.

\section{Rancangan Percobaan}

Penelitian dilakukan dengan pembuatan ekstrak cascara dan pembuatan mikroemulsi ekstrak cascara. Penelitian menggunakan Rancangan Acak Lengkap (RAL) dengan dua faktor yaitu jenis minyak (minyak kelapa dan minyak kelapa sawit) dan variasi rasio ekstrak cascara:aquades $(0: 100 ; 50: 50 ; 100: 0)$. Penelitian ini dilakukan dengan menggunakan batas nilai HLB 14,5 untuk pembuatan mikoemulsi menggunakan minyak kelapa dan nilai HLB 14 untuk pembuatan mikroemulsi menggunakan minyak kelapa sawit serta variasi rasio minyak dan surfaktan adalah 15:85 dan variasi rasio minyak-surfaktan dengan air $1: 8$

\section{Metode Analisis}

Uji Stabilitas Dipercepat (Cho et al.,

Pada pengujian stabilitas mikroemulsi minyak kelapa dan minyak kelapa sawit dengan penambahan ekstrak cascara yang dipercepat dilakukan dengan dua cara yaitu sentrifugasi dan pemanasan. Pada uji sentrifugasi, sebanyak $10 \mathrm{ml}$ mikroemulsi disentrifugasi pada $2300 \mathrm{rpm}$ selama 15 menit, setelah itu dimasukkan pada kuvet dan diukur absorbansinya pada $\lambda=502 \mathrm{~nm}$. Pada saat uji pemanasan, sebanyak $10 \mathrm{ml}$ mikroemulsi pada tabung reaksi dilakukan pemanasan di dalam oven dengan suhu $105^{\circ} \mathrm{C}$ selama 5 jam, setelah itu dimasukkan pada kuvet dan diukur absorbansinya pada $\lambda=502 \mathrm{~nm}$.

\section{Uji Stabilitas dengan Penyimpanan (Cho et al., 2008)}

Pada pengujian stabilitas mikroemulsi minyak kelapa dan minyak kelapa sawit dengan penambahan ekstrak cascara pada penyimpanan dilakukan dengan menyimpan $30 \mathrm{ml}$ mikroemulsi dalam botol transparan dengan suhu ruang selama 8 minggu, kemudian dilakukan pengukuran nilai absorbansi mikroemulsi yang dimasukkan pada kuvet tiap 2 minggu. Pengamatan dilakukan pada minggu ke- 0; 2; 4; 6 dan 8. Stabilitas mikroemulsi ditentukan dengan menera absorbansi pada $\lambda=502 \mathrm{~nm}$ menggunakan spectrometer.

\section{Pengujian Total Polifenol (Slinkard dan Singleton, 1977)}

Untuk menghitung kandungan total polifenol dalam mikroemulsi ekstrak cascara digunakan metode follin Ciocalteu sesuai dengan metode yang dikembangkan oleh Slinkard dan Singleton (1977). Sampel mikoremulsi sebanyak $0,1 \mathrm{ml}$ dimasukkan ke dalam tabung reaksi dan ditambahkan 4,9 ml aquades. Setelah itu ditambahkan reagen follin ciocalteu sebanyak $0,5 \mathrm{ml}$ kedalam tabung reaksi, lalu divortex dan didiamkan selama 5 menit. Selanjutnya dimasukkan $1 \mathrm{ml}$ larutan $\mathrm{Na}_{2} \mathrm{CO}_{3} \quad 7 \%$ kemudian divortex agar larutan homogen. Kemudian tabung reaksi didiamkan ditempat gelap selama 60 menit. Setelah itu diukur nilai absorbansinya menggunakan spektrofotometer pada panjang gelombang $765 \mathrm{~nm}$. Larutan blanko dibuat dengan cara yang sama tetapi dengan mengganti sampel menggunakan aquades pada jumlah yang sama. Total polifenol dihitung dengan menggunakan kurva standar yang dibuat dari asam galat pada beberapa konsentrasi. Total fenol dalam sampel dinyatakan sebagai mg GAE/ml, $\mathrm{GAE}=$ gallic acid equivalent . 


\section{Pengujian Aktivitas Antioksidan Metode DPPH (Yamaguchi, 1998)}

Aktivitas antioksidan dianalisis berdasarkan kemampuannya menangkap radikal bebas (Radical Scavenging Activity/RSA) diphenylpicrylhydrazyl (DPPH), dan dihitung sebagai persen penghambatan terhadap DPPH, menurut metode yang dikembangkan oleh Yamaguchi et al. (1998) dengan modifikasi. Mengambil 0,1 ml sampel dan dimasukkan ke dalam tabung reaksi, ditambahkan 2,95 ml metanol. $3 \mathrm{ml}$ larutan DPPH $300 \mu \mathrm{M}$ ditambahkan ke dalam sampel ditera dengan kemudian divortex. Setelah itu didiamkan selama 30 menit. Diukur nilai absorbansi menggunakan spektrofotometer pada panjang gelombang 517 nm. Blanko dibuat dengan cara mengganti sampek dengan methanol. Aktivitas antioksidan dihitung dengan rumus:

Aktivitas antioksidan (\%)

$=\frac{\text { Absorbansi blanko }- \text { absorbansi sampel }}{\text { Absorbansi blanko }} \times 100 \%$

\section{HASIL DAN PEMBAHASAN}

Stabilitas Mikroemulsi Minyak Kelapa dan Minyak Kelapa Sawit dengan Penambahan Ekstrak Cascara

Stabilitas Mikroemulsi setelah Sentrifugasi dan Pemanasan

Stabilitas mikroemulsi ekstrak cascara pada tingkat konsentrasi yang sama terhadap sentrifugasi menunjukkan kestabilan yang tinggi yang ditunjukkan dengan nilai absorbansi tidak berbeda nyata $(\mathrm{P}<0,05)$ dibandingkan dengan nilai absorbansi mikroemulsi ekstrak cascara sebelum disentrifugasi (H0) (Gambar 1). Hal ini mengindikasikan sentrifugasi tidak menyebabkan mikroemulsi ekstrak cascara yang terdispersi terpisah dengan fase kontinyunya. Meskipun terjadi penurunan nilai absorbansi, namun hasil analisis statistik menunjukkan penurunan yang tidak berbeda nyata.

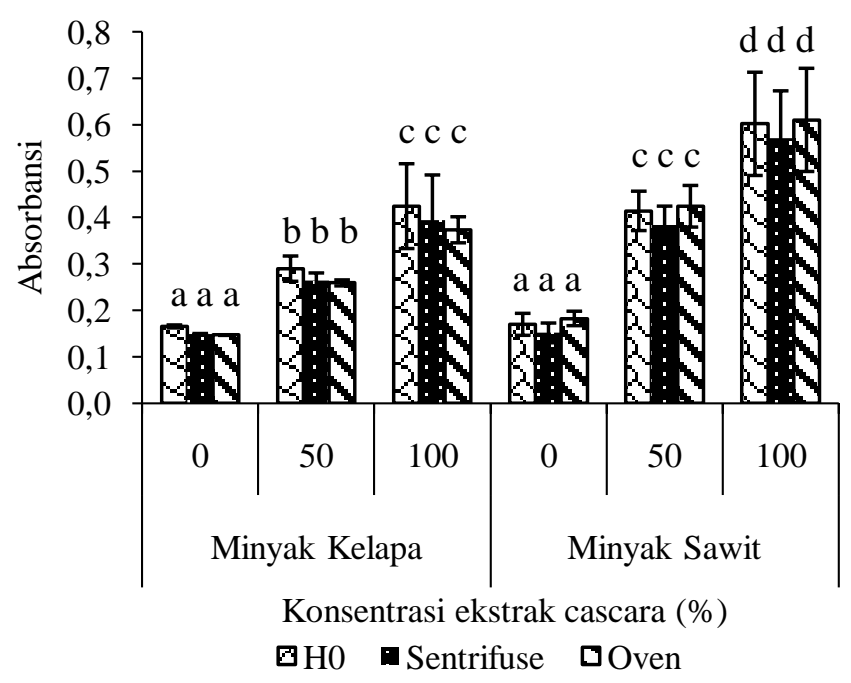

Gambar 1. Nilai absorbansi mikroemulsi minyak kelapa dan minyak kelapa sawit dengan variasi penambahan ekstrak cascara dan dengan metode uji stabilitas menggunakan sentrifugasi dan pemanasan

Sentrifugasi berfungsi untuk memisahkan larutan berdasarkan densitas yang berbeda, namun mikroemulsi memiliki tegangan permukaan yang rendah sehingga menyebabkan mikroemulsi tidak memisah apabila diberi pelakuan sentrifugasi. Berbeda dengan sistem emulsi. Emulsi merupakan sistem yang tidak stabil secara termodinamika terdiri dari dua atau lebih fase larutan yang tidak saling bercampur, dimana salah satunya terdispersi sebagai globul-globul dalam fase cair lainnya. Penelitian yang dilakukan oleh Sari (2015), dimana emulsi menjadi terpisah (tidak stabil) apabila diberi perlakuan pengadukan.

Mikroemulsi ekstrak cascara pada tingkat konsentrasi yang sama, apabila dipanaskan selama 5 jam pada suhu $105^{\circ} \mathrm{C}$ mengalami penurunan dan kenaikan nilai absorbansi yang tidak berbeda nyata $(\mathrm{P}<0,05)$ dibandingkan mikroemulsi ekstrak cascara sebelum dipanaskan ( $\mathrm{H} 0)$. Hal ini menunjukkan bahwa mikroemulsi 
masih tetap stabil meskipun diberi perlakuan suhu tinggi. Mikroemulsi merupakan sistem yang stabil secara termodinamika (Flanagan dan Sigh 2006). Apabila diberi perlakuan suhu tinggi, maka mikroemulsi akan tetap stabil, berbeda dengan sistem emulsi yang akan terpisah antara fase terdispersinya.

Perbedaan penambahan jumlah ekstrak cascara $(0 \%, 50 \%$ dan 100\%) menunjukkan peningkatan absorbansi yang berbeda nyata $(\mathrm{P}>0,05)$. Perbedaan jenis minyak yaitu minyak kelapa dan minyak kelapa sawit menujukkan hasil berbeda nyata $(\mathrm{P}>0,05)$ kecuali pada mikroemulsi dengan pemberian ektrak cascara $0 \%$. Nilai absorbansi mikroemulsi minyak kelapa dan minyak kelapa sawit dengan penambahan ekstrak cascara ditunjukkan pada Gambar 1.

Gambar 1 menunjukkan nilai absorbansi mikroemulsi yang menggunakan minyak kelapa sawit lebih tinggi dibanding dengan minyak kelapa dan menunjukkan hasil yang berbeda nyata pada penambahan ekstrak cascara konsentrasi $50 \%$ dan $100 \%$. Hal ini disebabkan karena minyak kelapa tersusun oleh asam lemak jenuh lebih dari 90\% dan asam lemak rantai sedang medium chain triglyceride (Silalahi dan Nurbaya, 2011). Karakteristik tersebut memungkinkan minyak kelapa stabil terhadap oksidasi dan akan memungkinkan surfaktan lebih mudah menyelubungi partikel minyak (Hunter, 1994).

Pemberian jumlah ekstrak cascara juga menunjukkan hasil yang berbeda nyata terhadap nilai absorbansi mikroemulsi. Semakin banyak jumlah ekstrak cascara yang ditambahkan maka semakin tinggi pula nilai absorbansinya. Hal ini kemungkinan disebabkan karena dalam ekstrak cascara mengandung tanin dan antosianin yang memberikan kontribusi warna terhadap mikroemulsi. Sehingga nilai absrobansi mikroemulsi meningkat. Antosianin merupakan golongan flavonoid yang mampu memberikan warna kuning hingga merah dan biru. Selain itu dengan ditambahkannya ekstrak cascara akan menyebabkan pergeseran formulasi mikroemulsi. Salager et al. (2005), menyatakan bahwa formulasi dalam pembuatan mikroemulsi sangat penting karena sifat sistem surfaktan-minyak-air pada pembentukan mikroemulsi sangat sensitif terhadap formulasi. Sedikit pergeseran dari formulasi yang tepat dapat menyebabkan perubahan drastis pada sifat mikroemulsi.

\section{Stabilitas Mikroemulsi Selama \\ Penyimpanan pada Suhu Ruang}

Stabilitas mikroemulsi selama penyimpanan ditentukan dengan melihat slope nilai absorbansi mikroemulsi minyak kelapa dan minyak kelapa sawit dengan penambahan ekstrak cascara setelah dilakukan penyimpanan pada suhu ruang selama 8 minggu (Gambar 2).

Hasil pengamatan absorbansi mikroemulsi pada penelitian ini setelah penyimpanan selama 8 minggu menunjukkan semakin lama waktu penyimpanan, kestabilan mikroemulsi cenderung menurun, yang ditandai dengan semakin meningkatnya nilai absorbansi. Hal ini diduga terjadi karena adanya gaya kohesif yang menyebabkan droplet-droplet minyak saling mendekat membentuk droplet yang lebih besar (koalesensi) selama penyimpanan, sebagaimana pendapat Lachman (1994). Menurut Dai et al. (2014), peningkatan ukuran droplet minyak mikroemulsi $\mathrm{O} / \mathrm{W}$ selama penyimpanan disebabkan karena aglomerasi maupun fusi dari droplet. Selain itu juga, diduga semakin lama penyimpanan pada suhu kamar, menyebabkan intensitas pengikatan antara minyak, surfaktan, dan air pada mikroemulsi semakin menurun sehingga stabilitasnya menurun. 


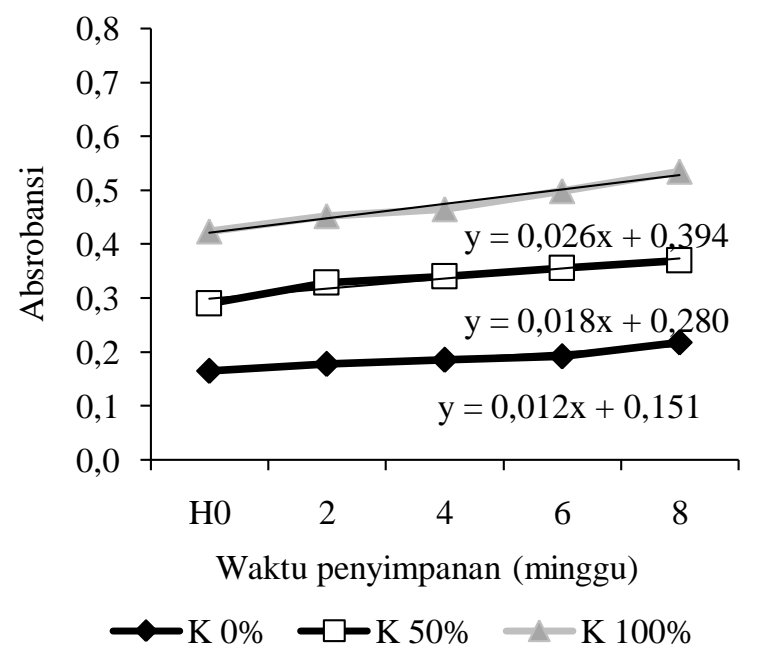

(a)

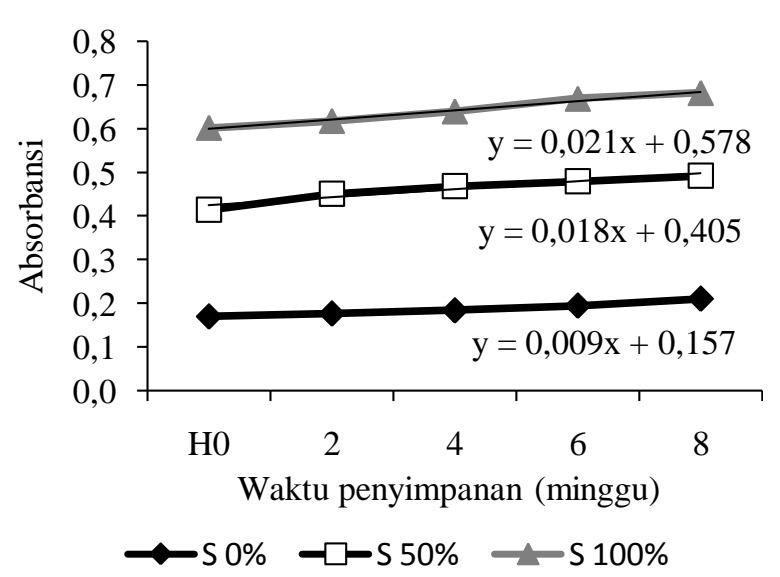

(b)

Gambar 2. Nilai slope absorbansi mikroemulsi pada (a). minyak kelapa (K) dan (b). minyak kelapa sawit (S) dengan variasi penambahan ekstrak cascara selama penyimpanan 8 minggu dalam suhu ruang

Hasil ANOVA terhadap nilai slope garis linier yang terbentuk dari pengukuran nilai absorbansi selama penyimpanan 8 minggu menunjukkan bahwa nilai slope dari perlakuan variasi minyak dan konsentrasi cascara tidak berbeda nyata $(\mathrm{P}<0,05)$. Hal ini menunjukkan bahwa variasi minyak dan konsentrasi cascara tidak mempengaruhi stabilitas mikroemulsi selama penyimpanan.

Mikroemulsi memiliki kelebihan dibandingkan dengan emulsi, tegangan antar muka pada mikroemulsi sangat rendah, sehingga menyebabkan mikroemulsi lebih stabil dalam penyimpanan (Goodwin, 2004). Berbeda dengan sistem emulsi, yang akan mengalami pemisahan (tidak stabil) selama penyimpanan. Seperti penelitian yang dilakukan Sari et al. (2015) semakin lama waktu penyimpanan emulsi akan terbentuk creaming yang merupakan pemisahan antar fase yang disebabkan oleh gaya gravitasi dan naiknya tegangan permukaan antara fase yang menyebabkan terjadinya pemisahan antar fase (Caserta et al., 2006), sedangkan pada penelitian ini, mikroemulsi yang dilakukan penyimpanan selama 8 minggu tidak terjadi pemisahan fase yang disebabkan oleh gaya gravitasi. Hal ini disebabkan karena mikroemulsi memiliki tegangan antarmuka yang sangat rendah sehingga ketika dilakukan penyimpanan selama 8 minggu, mikroemulsi masih tetap stabil.

\section{Total Polifenol Mikroemulsi Minyak} Kelapa dan Minyak Kelapa Sawit dengan Penambahan Ekstrak Cascara Total Polifenol Mikroemulsi Setelah Sentrifugasi dan Pemanasan

Stabilitas total polifenol mikroemulsi minyak kelapa dan minyak kelapa sawit dengan penambahan ekstrak cascara dapat ditentukan dengan melakukan pemanasan dan sentrifugasi terhadap mikroemulsi yang terbentuk. Metode yang digunakan untuk pengukuran total polifenol yaitu menggunakan metode follin Ciocalteu. Perubahan nilai total polifenol dapat dikatakan stabil apabila diuji ANOVA menunjukkan hasil yang tidak signifikan. Nilai total polifenol disajikan pada Gambar 3.

Stabilitas nilai total polifenol mikroemulsi ekstrak cascara terhadap sentrifugasi menunjukkan kestabilan yang tinggi yang ditunjukkan dengan nilai absorbansi tidak berbeda nyata $(\mathrm{P}<0,05)$ dibandingkan dengan nilai absorbansi mikroemulsi ekstrak cascara sebelum disentrifugasi (H0). Hal ini 
mengindikasikan sentrifugasi tidak menyebabkan nilai total polifenol mengalami penurunan. Meskipun terjadi penurunan nilai total polifenol, namun hasil statistik menunjukkan penurunan yang tidak berbeda nyata.

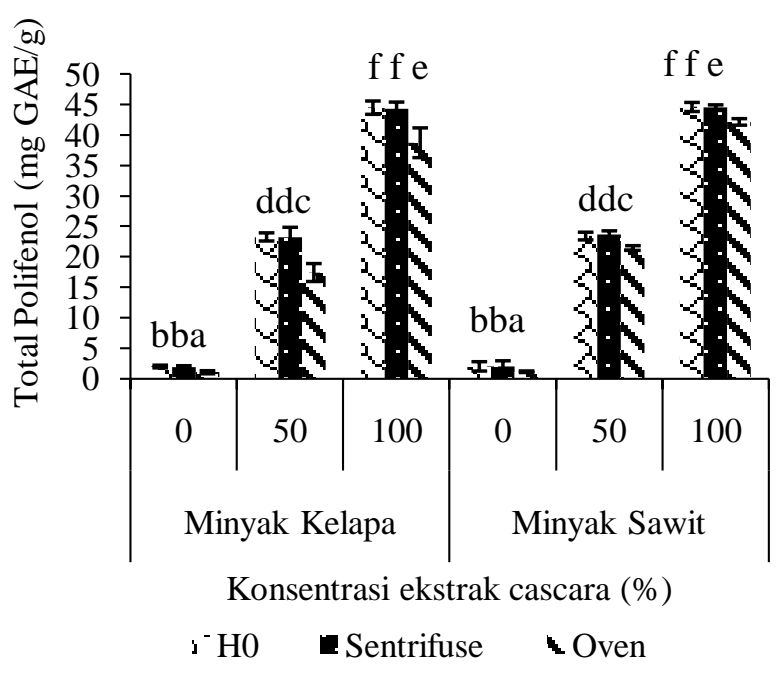

Gambar 3. Nilai total polifenol mikroemulsi minyak kelapa dan minyak kelapa sawit dengan variasi penambahan ekstrak cascara dan dengan metode uji stabilitas menggunakan sentrifugasi dan pemanasan

Nilai total polifenol mikroemulsi ekstrak cascara yang dipanaskan selama 5 jam pada suhu $105^{\circ} \mathrm{C}$ mengalami penurunan yang berbeda nyata $(\mathrm{P}>0,05)$ dibandingkan mikroemulsi ekstrak cascara sebelum dipanaskan (H0). Hal ini menunjukkan bahwa nilai total polifenol mengalami penurunan ketika diberi perlakuan suhu tinggi. Hal ini disebabkan karena, senyawa polifenol rentan terhadap suhu tinggi. Proses pemanasan merupakan faktor terbesar yang menyebabkan kerusakan antosianin (Astawan dan Kasih, 2008). Berdasarkan penelitian Cisse, (2009) pada suhu berkisar $70-90^{\circ} \mathrm{C}$ menunjukkan laju oksidasi antosianin yang tinggi. Namun untuk perlakuan sntrifugasi menunjukkan penurunan nilai yang tidak berbeda nyata, yang artinya dengan senyawa polifenol yang terkandung dalam ekstrak cascara tidak mengalami kerusakan apabila diberi perlakuan sentrifugasi.

Perbedaan jenis minyak yaitu minyak kelapa dan minyak kelapa sawit menujukkan hasil yang tidak berbeda nyata $(\mathrm{P}<0,05)$. Namun untuk perbedaan penambahan jumlah ekstrak cascara $(0 \%$, $50 \%$ dan $100 \%$ ) menunjukkan hasil pengukuran yang berbeda nyata $(\mathrm{P}>0,05)$.

Gambar 3 menunjukkan bahwa semakin besar konsentrasi ekstrak cascara yang ditambahkan, maka nilai total polifenolnya semakin tinggi. Hal ini disebabkan karena dalam ekstrak cascara mengandung senyawa polifenol yaitu berupa antosianin dan tanin. Seperti yang dilaporkan dalam Mahesa (2012) menyatakan bahwa cascara mengandung flavan-3ol, asam hidroksiamat, flavanol, antosianidin, katekin, epikatekin, rutin, tannin dan asam ferulat. Dengan hal ini maka semakin banyak konsentrasi ekstrak cascara yang ditambahkan maka nilai total polifenol semakin tinggi. Namun untuk variasi penggunaan minyak, tidak menunjukkan hasil yang berbeda nyata. Hal ini dikarenakan di dalam minyak kelapa dan minyak kelapa sawit tidak mengandung senyawa polifenol sehingga tidak mempengaruhi nilai total polifenol.

\section{Total Polifenol Mikroemulsi selama} Penyimpanan pada Suhu Ruang

Stabilitas nilai total polifenol mikroemulsi minyak kelapa dan minyak kelapa sawit dengan penambahan ekstrak cascara selama penyimpanan ditentukan dengan melihat slope nilai total polifenol selama penyimpanan 8 minggu dalam suhu ruang. Nilai total polifenol mikroemulsi ekstrak cascara selama penyimpanan 8 minggu dapat disajikan pada Gambar 4. 


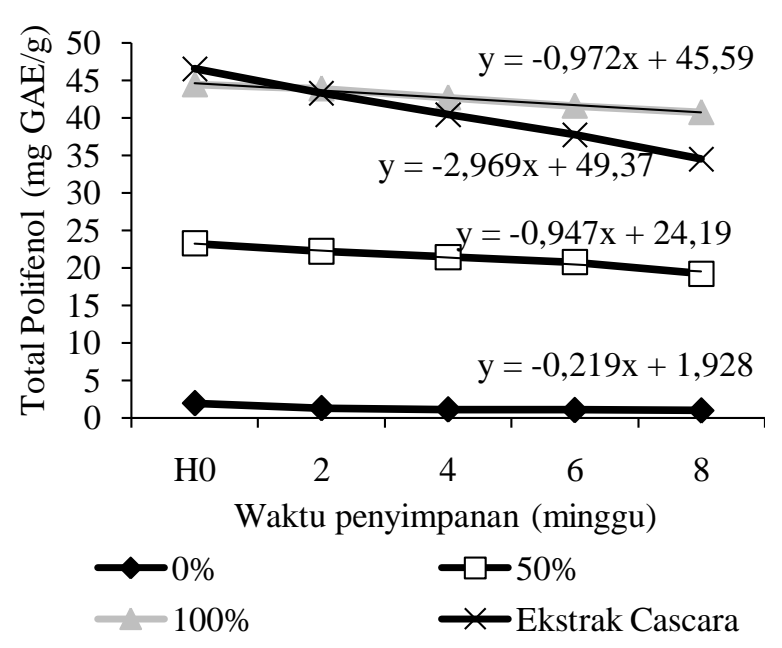

(a)

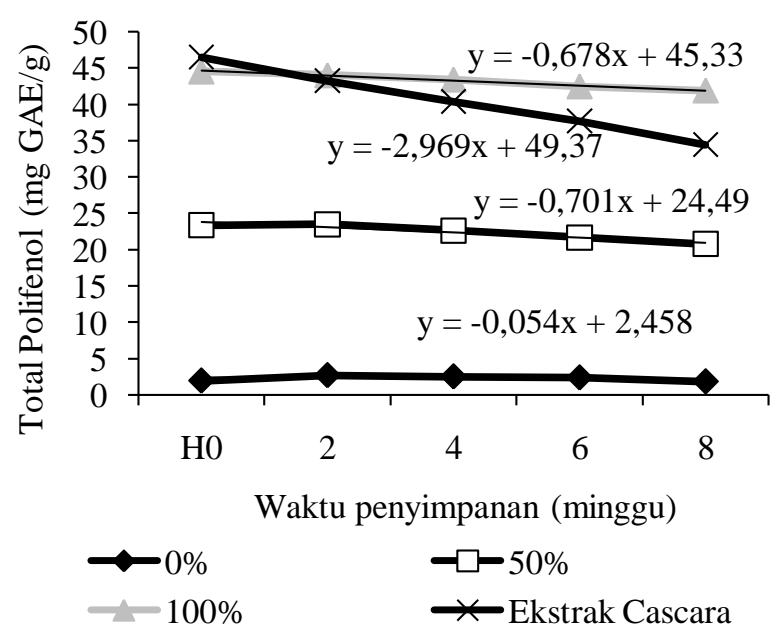

(b)

Gambar 4. Nilai slope total polifenol mikroemulsi (a). minyak kelapa dan (b). minyak kelapa sawit variasi dengan penambahan ekstrak cascara selama penyimpanan 8 minggu dalam suhu ruang

Hasil ANOVA terhadap nilai slope garis linear yang terbentuk dari pengukuran nilai total polifenol selama penyimpanan menunjukkan bahwa variasi jenis minyak tidak berpengaruh signifikan terhadap nilai slope $(\mathrm{P}<0,05)$. Variasi konsentrasi berpengaruh signifikan terhadap nilai slope $(\mathrm{P}>0,05)$. Ekstrak cascara mengandung beberapa senyawa polifenol, yang mudah rusak selama penyimpanan. Hal inilah yang menyebabkan slope (penurunan nilai total polifenol) signifikan. Hal ini sesuai dengan pendapat Houghton (1998) bahwa antosianin akan teroksidasi perlahan-lahan saat terlarut di dalam suatu larutan campuran, sedangkan dalam komposisi minyak kelapa dan minyak kelapa sawit tidak mengandung senyawa polifenol, sehingga variasi jenis minyak tidak berpengaruh signifikan terhadap penurunan nilai total polifenol.

Gambar 4 menunjukkan nilai total polifenol ekstrak cascara mengalami menurunan yang lebih drastis dibandingkan dengan nilai total polifenol mikroemulsi. Hal ini dikarenakan sistem mikroemulsi efektif untuk melindungi bahan-bahan yang sensitif terhadap oksidasi. Antosianin sangat sensitif terhadap oksigen dan cahaya karena mudah teroksidasi (Houghton, 1998). Cho et al. (2008) mencoba memasukkan DHA dalam mikroemulsi, dan menunjukkan bahwa minyak DHA yang tidak disimpan dalam mikroemulsi menunjukkan peningkatan oksidasi lebih cepat dianding dengan minyak DHA yang dimasukkan ke dalam mikroemulsi).

\section{Aktivitas Antioksidan Mikroemulsi Minyak Kelapa dan Minyak Kelapa Sawit dengan Penambahan Ekstrak Cascara}

Aktivitas Antioksidan Mikroemulsi setelah Sentrifugasi dan Pemanasan

Stabilitas aktivitas antioksidan mikroemulsi minyak kelapa dan minyak kelapa sawit dengan penambahan ekstrak cascara dapat ditentukan dengan melakukan pemanasan dan sentrifugasi terhadap mikroemulsi. Uji ini dilakukan untuk mengetahui kemampuan antioksidan dari mikroemulsi ekstrak cascara. Uji aktivitas antioksidan dilakukan dengan menggunakan metode peredaman radikal bebas DPPH. Perubahan nilai aktivitas antioksidan dapat dikatakan stabil apabila diuji ANOVA menunjukkan hasil yang tidak signifikan. Nilai aktivitas antioksidan disajikan pada Gambar 5. 


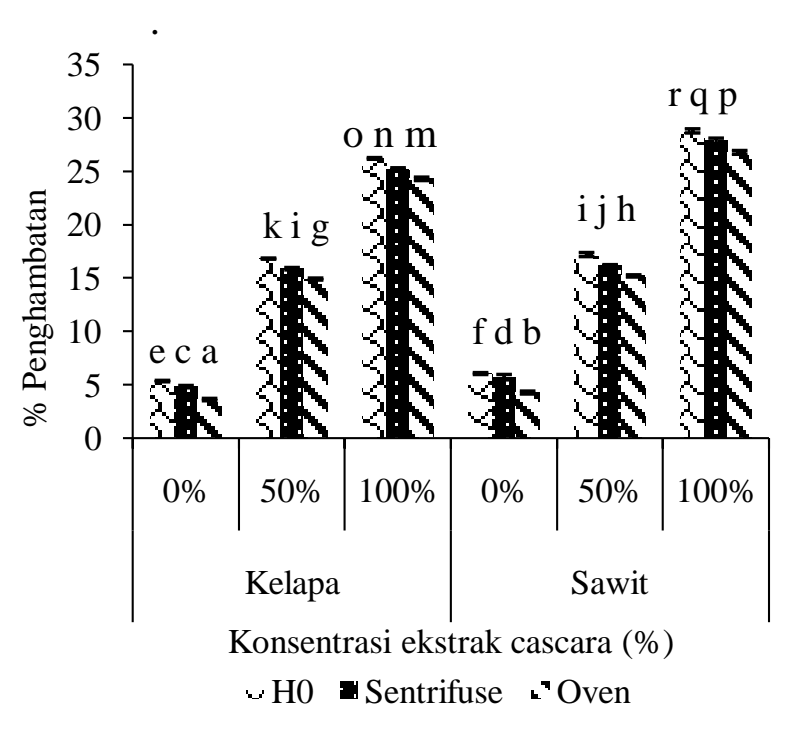

Gambar 5. Nilai aktivitas antioksidan mikroemulsi minyak kelapa dan minyak kelapa sawit dengan variasi penambahan ekstrak cascara dan dengan metode uji stabilitas menggunakan sentrifugasi dan pemanasan

Hasil ANOVA terhadap nilai aktivitas antioksidan menunjukkan hasil yang berbeda nyata $(\mathrm{P}>0,05)$ pada perlakuan variasi minyak, variasi konsentrasi cascara, perlakuan sentrifugasi dan oven. Hal ini mengindikasikan bahwa jenis minyak, konsentrasi ekstrak, sentrifugasi dan pemanasan menyebabkan nilai aktivitas antioksidan mengalami penurunan yang cukup drastis

Gambar 5 menunjukkan bahwa semakin tinggi konsentrasi ekstrak cascara yang ditambahkan, maka nilai aktivitas antioksidan semakin tinggi. Hal ini disebabkan karena dalam ekstrak cascara mengandung senyawa yang memiliki sifat oksidan. Dari beberapa penelitian yang telah dilakukan, senyawa polifenol pada cacscara yaitu flavan-3-ol, asam hidroksinamat, flavonol, antosianin, katekin, tanin dan asam ferulat (Esquivel dan Jimenez 2012). Semakin banyak ekstrak cascara yang ditambahkan, maka nilai aktivitas antioksidan juga semakin meningkat.

Selain penambahan konsentrasi ekstrak cascara, penggunaan jenis minyak juga berpengaruh signifikan terhadap nilai aktivitas antioksidan. Mikroemulsi yang menggunakan minyak sawit memiliki nilai aktivitas antioksidan yang lebih tinggi apabila dibandingkan dengan mikroemulsi minyak kelapa. Hal ini disebabkan karena minyak kelapa sawit mengandung komponen minor berupa karatenoid dan tokoferol (Ketaren, 2008). Tokoferol dapat mencegah proses oksidasi dengan memberikan elektron. Sebagai antioksidan, vitamin $\mathrm{E}$ berperan pada regulasi sinyal seluler, proliferasi sel, ekspresi gen, serta memicu radikal peroksil lipid dengan menyumbangkan atom hidrogen pada Reactive Oxygen Species atau ROS (Devaraj et al., 2007). Oleh karena itu, dengan penggunaan minyak kelapa sawit memiliki nilai aktivitas antioksidan yang lebih tinggi dari mikroemulsi minyak kelapa.

Perlakuan oven dan sentrifugasi juga menunjukkan hasil yang berbeda nyata. Nilai aktivitas antioksidan mengalami penurunan setelah dilakukan sentrifugasi dan pemanasan. Hal ini disebabkan karena antosianin mudah rusak oleh pemberian suhu tinggi. Proses pemanasan merupakan faktor terbesar yang menyebabkan kerusakan antosianin (Astawan dan Kasih, 2008). Berdasarkan penelitian Cisse, (2009) pada suhu berkisar $70-90^{\circ} \mathrm{C}$ menunjukkan laju degradasi antosianin yang tinggi. Selain itu, $\beta$ karoten sensitif terhadap cahaya panas dan oksigen. Haris dan Karmas (1989) menyatakan bahwa senyawa karoten akan mengalami penurunan atau mengalami kerusakan yang nyata pada suhu diatas $80^{\circ} \mathrm{C}$. Hal inilah yang menyebabkan nilai aktivitas antioksidan mengalami penurunan setelah dilakukan oven suhu $105^{\circ} \mathrm{C}$ selama 5 jam.

\section{Aktivitas Antioksidan Mikroemulsi selama Penyimpanan pada Suhu Ruang}

Stabilitas nilai aktivitas antioksidan mikroemulsi minyak kelapa dan minyak kelapa sawit dengan penambahan ekstrak cascara selama penyimpanan ditentukan 
dengan melihat slope nilai aktivitas antioksidan selama penyimpanan 8 minggu dalam suhu ruang. Nilai aktivitas antioksidan mikroemulsi ekstrak cascaa selama penyimpanan 8 minggu dtunjukkan oleh Gambar 6.

$\begin{array}{rrr}\text { Nilai } & \text { aktivitas } & \text { antioksidan } \\ \text { mengalami } & \text { penurunan } & \text { selama }\end{array}$ penyimpanan 8 minggu dalam suhu ruang (Gambar 6). Senyawa antioksidan yang terkandung dalam mikroemulsi yaitu berasal dari sumber minyak dan ekstrak cascara. Dalam ekstrak cascara mengandung senyawa flavan-3-ol, asam hidroksinamat, flavonol, antosianidin, katekin, rutin, tanin, asam ferulat (Esquivel dan Jimenez 2012). Pada minyak kelapa sawit mengandung komponen minor berupa karatenoid dan tokoferol (Ketaren, 2008). Salah satu sifat dari antosianin yaitu mudah teroksidasi. Selama penyimpanan 8 minggu kemungkinan antosianin mengalami oksidasi, seperti yang dinyatakan dalam Houghton (1998), saat terlarut di dalam suatu larutan campuran, antosianin akan teroksidasi perlahan-lahan. Sama halnya dengan antosianin, beta karoten umumya sensitif terhadap cahaya, panas, dan oksigen (Haris dan Karmas, 1989). Selama penyimpanan 8 minggu dimungkinkan bahwa mikroemulsi terkena cahaya, oleh karena itu dapat menyebabkan penurunan nilai aktivitas antioksidan.

Hasil ANOVA terhadap nilai slope garis linier yang terbentuk dari pengukuran nilai aktivitas antioksidan selama penyimpanan 8 minggu menunjukkan bahwa nilai slope dari perlakuan variasi minyak dan konsentrasi cascara berbeda nyata $(\mathrm{P}>0,05)$. Hal ini menunjukkan bahwa variasi minyak dan konsentrasi cascara mempengaruhi stabilitas nilai aktivitas antioksidan mikroemulsi minyak kelapa dan minyak kelapa sawit dengan penambahan ekstrak cascara selama penyimpanan 8 minggu dalam suhu ruang.

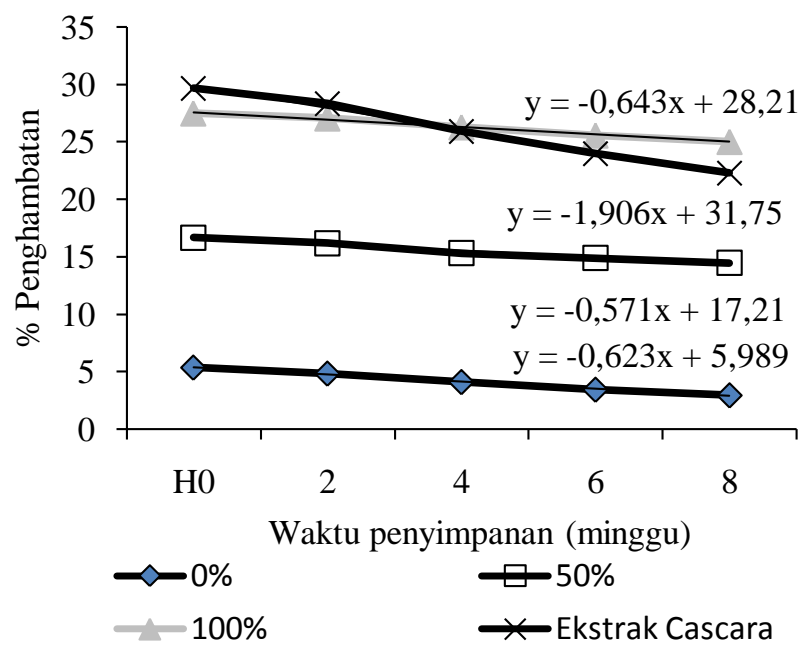

(a)

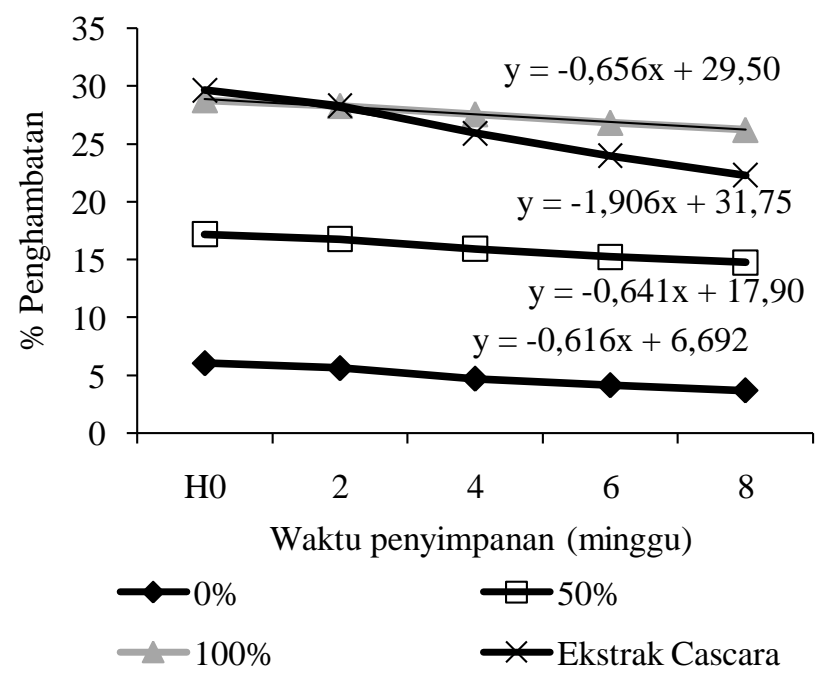

(b)

Gambar 6. Nilai slope aktivitas antioksidan mikroemulsi minyak kelapa (a) dan minyak kelapa sawit (b) dengan variasi penambahan ekstrak cascara selama penyimpanan 8 minggu dalam suhu ruang

Bahan yang mengandung senyawa antioksidan dalam mikroemulsi tersebut yaitu ekstrak cascara dan sumber minyak. Kandungan antioksidan pada cascara yaitu adalah flavan-3-ol, asam hidroksinamat, flavonol, antosianidin, katekin, epikatekin, rutin, tanin, asam ferulat (Esquivel dan Jimenez, 2012). Senyawa tersebut mudah rusak ketika mengalami penyimpanan. Antosianin mudah mengalami oksidasi saat terlarut di dalam suatu larutan 
campuran (Houghton, 1998). Hal inilah yang menyebabkan slope (penurunan nilai aktivitas antioksidan) cukup drastis atau signifikan. Sedangkan dalam komposisi minyak kelapa sawit juga terdapat komponen minor berupa karatenoid dan tokoferol (Ketaren, 2008). Kandungan bahan tersebut yang berpengaruh terhadap nilai aktivitas antioksidan. Karatenoid dan tokoferol memiliki sifat mudah teroksidasi Sehingga variasi jenis minyak juga berpengaruh signifikan terhadap penurunan nilai aktivitas antioksidan. $\beta$ karoten umumya sensitif terhadap cahaya, panas, dan oksigen (Haris dan Karmas, 1989).

Gambar 6 menunjukkan nilai aktivitas antioksidan ekstrak cascara mengalami menurunan yang lebih drastis dibandingkan dengan nilai aktivitas antioksidan mikroemulsi. Hal ini dikarenakan sistem mikroemulsi efektif untuk melindungi bahan-bahan yang sensitif terhadap oksidasi. Seperti yang diketahui antosianin sangat sensitif terhadap oksigen dan cahaya karena mudah teroksidasi (Houghton, 1998). Cho et al. (2008) mencoba memasukkan DHA dalam mikroemulsi, dan menunjukkan bahwa minyak DHA yang tergabung dalam mikroemulsi menunjukkan stabilitas oksidasi yang lebih tinggi daripada minyak DHA bebas yang tidak disimpan dalam mikroemulsi.

\section{KESIMPULAN}

Variasi jenis jenis minyak berpengaruh signifikan terhadap stabilitas mikroemulsi. Penggunaan minyak kelapa sawit menghasilkan nilai absorbansi yang lebih tinggi dibandingkan minyak kelapa. Variasi konsentrasi ekstrak cascara berpengaruh signifikan terhadap stabilitas. Nilai absrobansi mikroemulsi semakin meningkat seiring dengan penambahan ekstrak cascara.

Variasi konsentrasi ekstrak cascara berpengaruh signifikan terhadap nilai total polifenol dan aktivitas antioksidan.
Semakin banyak konsentrasi yang ditambahkan maka dapat meningkatkan nilai total polifenol dan aktivitas antioksidan.

\section{DAFTAR PUSTAKA}

Akroman, R. 2015. "Formulasi Mikroemulsi Minyak Kelapa Sawit dalam Air Menggunakan Kombinasi Surfaktan Tween 80 dengan GMS atau Lesitin". Skripsi. Universitas Jember, Jember.

Ariviani, S. 2010. Total antosianin ekstrak buah salam dan korelasinya dengan kapasitas anti peroksidasi pada sistem linoelat. Jurnal Agrointek, 4 (2): 121127.

Amar, I., Aserin, A. and Garti, N. 2002. Solubilization patterns of lutein and lutein esters in food grade non ionik microemulsions. J. Agric. Food Chem., 51: 4775-4781.

Silalahi, J., dan S. Nurbaya. 2011. Komposisi, Distribusi dan Sifat Aterogenik Asam Lemak dalam Minyak Kelapa dan Kelapa Sawit. J. Indo. Med. Assoc, 61 (11): 454-456.

Cho, Y.H., Kim, S., Bae, E.K., Mok, C.K. and Park, J. 2008. Formulation of a cosurfactant-free $\mathrm{O} / \mathrm{W}$ microemulsion using nonionic surfactant mixtures. $J$. Food Sci., 73 (3): 115-121.

Cisse, M., Vaillant, F., Acosta, O., Mayer, C.D., dan Dornier, M. 2009. Thermal degradation kinetics of anthocyanins from blood orange, blackberry, and roselle using the arrhenius, Eyring, and Ball Models. J. Agric. Food Chem, 57: 6285-6291.

Esquivel, P., and Victor M. Jimenez. 2012. Functional properties of coffee and coffee by producetst. Food Research International, 46: 488495.

Flanagan, J. and Singh, H. 2006. Microemulsions : a Potential delivery system for bioactives in food. Cric. Rev. in Food Sci. and Nut., 46: 221237. 
Garti N, Yaghmur A, Leser ME, Clement V, Watzke HJ. 2001. Improved oil solubilizationin oil/water food grade microemulsions in the presence of polyols and ethanol. J Agric. Food Chem 51: 252-62.

Houghton, P.J. dan Raman, A. 1998. Laboratory Handbook for The Fractionation of Natural Extracts. Thomson Science, London.

Mahesa, M. F. 2012. "Esterifikasi Senyawa Polifenol dari Ekstrak Kulit Biji Kopi dengan Asam p-Hidroksibenzoat dengan Menggunakan Katalis $\mathrm{SiO}_{2}-$ $\mathrm{H}_{2} \mathrm{SO}_{4}$ ". Tesis. Fakultas MIPA, Universitas Indonesia.

Marcelinda, A., A. Ridhay, Prismawiyanti. 2016. Aktivitas antioksidan ekstrak limbah kulit ari biji kopi (Coffea sp.) berdasarkan tingkat kepolaran pelarut. Jurnal of Natural Science, 5 (1): 2130.

Salager, J.L., Anton, R.E., Sabatini, D.A., Harwell, J.H., Acosta, E.J., and Tolosa, L.I. 2005. Enhancing solubilization in microemulsions state of the art and current trends. Journal of Surfactants and Detergents, 8 (1): 3-21.

Silalahi, J., dan S. Nurbaya. 2011. Komposisi, distribusi dan sifat aterogenik asam lemak dalam minyak kelapa dan kelapa sawit. J. Indo. Med. Assoc., 61 (11): 454-456.

Slinkard, K. and V. L. Singleton. 1977. Total phenol analysis: Automation and comparison with manual methods. American Journal of Enology and Viticulture, 28: 49-55.

Spernath, A., Yaghmur, A., Aserin, A., Hoffman, R.E. and Garti, N. 2002. Food-grade microemulsions based on nonionic emulsifiers: Media to enhance lycopen solubilization. $J$. Agric. Food Chem., 50: 6917-6922.
Spernath, A., Yaghmur, A., Aserin, A., Hoffman, R.E. and Garti, N. 2003. Self-diffusion nuclear magnetic resonance, microstructure transitions, and solubilization capacity pf phytosterol and cholesterol in Winsor IV food-grade microemulsions. $J$. Agric. Food Chem., 51: 2359-2364.

Suhendra, L., Raharjo, S., Hastuti, P., Hidayat, C. 2014. Stabilitas mikroemulsi fucoxanthin dan efektifitasnya dalam menghambat foto oksidasi vitamin c pada model minuman. Agritech, 34 (2): 138-145.

Yuwanti, S., Raharjo, S., Hastuti, P dan Supriyadi. 2012. Mikroemulsi minyak dalam air (o/w) sebagai pembawa $\alpha$ tokoferol untuk menghambat sunlight flavor pada susu full cream akibat fotooksidasi. Agritech, 32 (2): 179185. 